Review

\title{
Protein Chemical Labeling Using Biomimetic Radical Chemistry
}

\author{
Shinichi Sato *(C) and Hiroyuki Nakamura * \\ Laboratory for Chemistry and Life Science, Institute of Innovative Research, Tokyo Institute of Technology, \\ Yokohama 226-8503, Japan \\ * Correspondence: shinichi.sato@res.titech.ac.jp (S.S.); hiro@res.titech.ac.jp (H.N.); Tel.: +81-45-924-5245 (S.S.); \\ +81-45-924-5244 (H.N.)
}

Academic Editor: Chryssostomos Chatgilialoglu

Received: 5 October 2019; Accepted: 31 October 2019; Published: 3 November 2019

\begin{abstract}
Chemical labeling of proteins with synthetic low-molecular-weight probes is an important technique in chemical biology. To achieve this, it is necessary to use chemical reactions that proceed rapidly under physiological conditions (i.e., aqueous solvent, $\mathrm{pH}$, low concentration, and low temperature) so that protein denaturation does not occur. The radical reaction satisfies such demands of protein labeling, and protein labeling using the biomimetic radical reaction has recently attracted attention. The biomimetic radical reaction enables selective labeling of the C-terminus, tyrosine, and tryptophan, which is difficult to achieve with conventional electrophilic protein labeling. In addition, as the radical reaction proceeds selectively in close proximity to the catalyst, it can be applied to the analysis of protein-protein interactions. In this review, recent trends in protein labeling using biomimetic radical reactions are discussed.
\end{abstract}

Keywords: biomimetic radical reaction; bioinspired chemical catalysis; protein labeling

\section{Introduction}

The development of a technique for covalent bond formation between a specific amino acid residue of a protein and a low-molecular-weight compound is an important issue in protein chemical labeling and the design of protein-based biomaterials. It is also indispensable for the development of antibody-drug conjugates (ADCs) that have attracted attention in recent years. In addition, a technique for selectively labeling a specific protein in a complex protein mixture is useful for the target identification of bioactive molecules. In order to achieve protein chemical labeling, it is essential to develop reactions that result in the formation of covalent bonds with natural proteins in water, at near-neutral $\mathrm{pH}$, at temperatures below $37^{\circ} \mathrm{C}$, and within a short reaction time of a few hours. Methods for labeling nucleophilic amino acid residues (lysine and cysteine residues) using compounds with electrophilic properties have been developed and have greatly contributed to the advancement of biochemistry. Additionally, site-selective protein labeling techniques [1] and enzymatic protein labeling techniques have been developed in recent years [2]. On the other hand, the chemical modification of amino acid residues, other than lysine and cysteine residues, has been extensively studied in recent years. The selective modification of tyrosine residue [3-12], tryptophan residue [3,13-18], methionine residue [19,20], peptide chain N-terminus [21,22], and the C-terminus [23] can also be used for protein functionalization. Radical reactions can modify amino acid residues that cannot be modified by conventional electrophilic methods, or modify proteins/peptides with a novel binding mode (e.g., stable $\mathrm{C}-\mathrm{C}$ bond formation). In this review, we focus on protein labeling reactions using the bioinspired single-electron transfer (SET) reaction. 


\section{Biomimetic Tyrosine Radical Labeling Using Enzymes}

In the biological radical reaction called radiolysis, water breaks down to highly reactive radicals such as hydroxyl radical, superoxide anion radical, and $\mathrm{H}_{2} \mathrm{O}_{2}$ [24]. Although the disulfide bond forming reaction is widely known as a response to oxidative stress in living systems, a dityrosine structure resulting from an oxidative cross-linking reaction of a tyrosine residue has also been reported as a protein oxidative modification marker $[25,26]$. Tyrosine readily undergoes SET under oxidative conditions to produce a highly reactive tyrosyl radical. A dityrosine structure is formed by the dimerization of tyrosine residues through the generation of tyrosyl radicals. Tyramide, a labeling agent that mimics tyrosine, forms a covalent bond with a tyrosine residue in a manner similar to dityrosine (Figure 1). Mimicking the biological response of dityrosine formation, metal complexes such as $\mathrm{Ni}(\mathrm{III})$ and $\mathrm{Ru}(\mathrm{III})$ were also reported to generate tyrosyl radicals and the radical species of tyramide. They were also used for protein cross-linking and protein labeling [27,28]. Several types of metalloenzymes, including peroxidase, tyrosinase [29-31], and laccase [32,33], catalyze the oxidation of tyrosine residues. As tyrosyl radical generation is efficiently catalyzed by peroxidases such as horseradish peroxidase (HRP), peroxidase was utilized as the catalyst in the dityrosine cross-linking reaction (Figure 1) [34-40]. $\mathrm{HRP}$ is activated by $\mathrm{H}_{2} \mathrm{O}_{2}$, and heme in the HRP molecule is transformed into a highly reactive species called compound I ([PPIX]+Fe(IV)O), which can abstract a single electron from tyrosine or tyramide with $\sim 1.1 \mathrm{~V}$ redox potential [41].

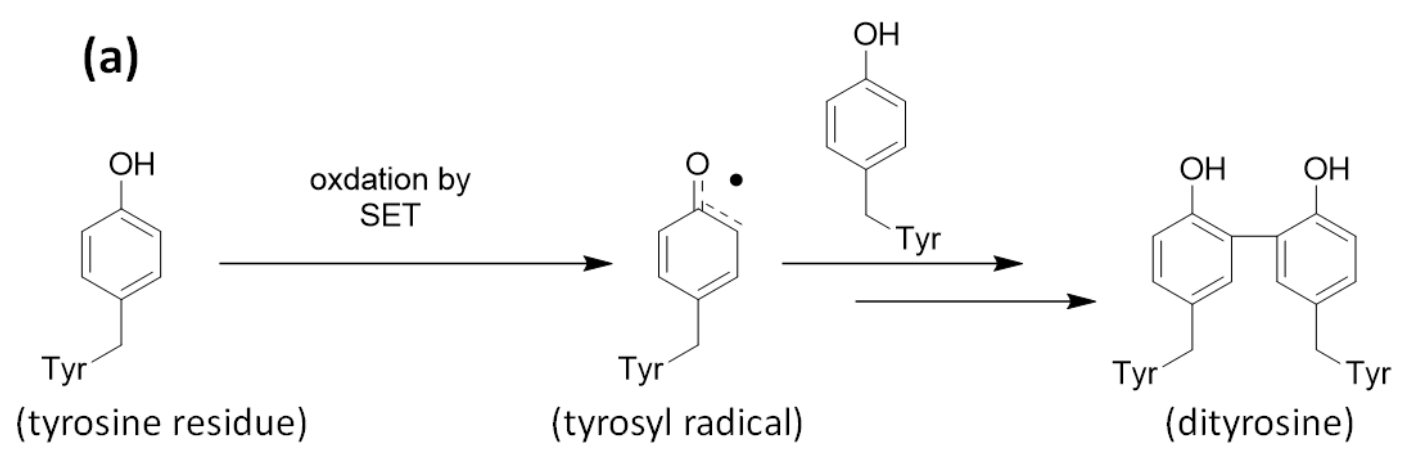

(b)<smiles>[R]C(=O)NCCc1ccc(O)cc1</smiles>

(c)

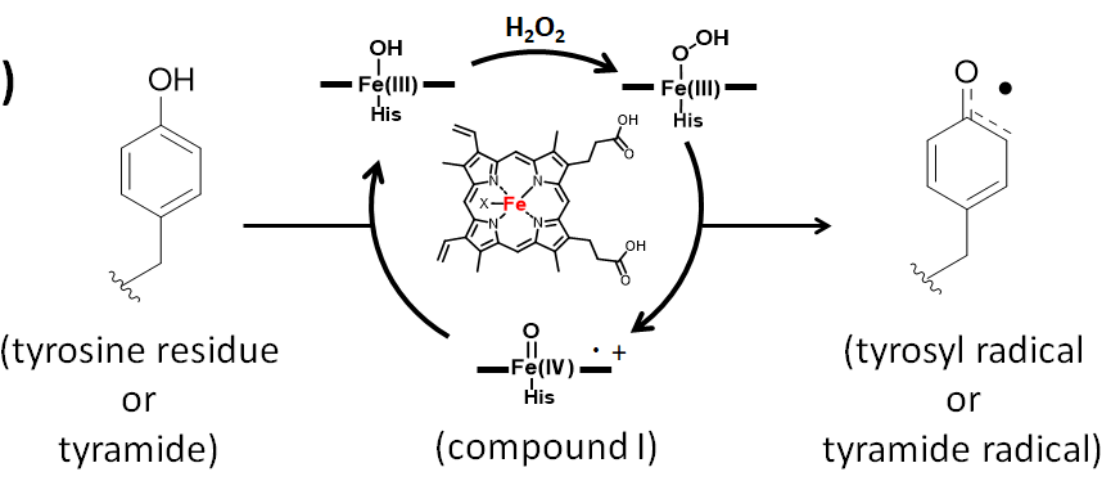

Figure 1. Generation of tyrosyl radical and tyramide radical. (a) Mechanism of dityrosine generation via single-electron transfer (SET). (b) Tyramide, a labeling agent that mimics tyrosine (c) Mechanism of oxidation in the active site of horseradish peroxidase (HRP). 
Aside from the tyrosine labeling reactions, other than mimicking dityrosine formation reaction, a tyrosine labeling reaction that uses 4-phenyl-1,2,4-triazoline-3,5-dione (PTAD) as the labeling agent was reported [10,42]. However, PTAD easily decomposes in water to form isocyanate, an active electrophile. Therefore, the resulting isocyanate reacts not only with tyrosine residues but also with electrophilic amino acid residues and the $N$-terminus. To achieve tyrosine-specific labeling, we developed tyrosine labeling agents based on the structure of luminol and found that tyrosine-specific labeling can be achieved under biomimetic radical oxidation conditions [43,44]. The idea originated from a reactive intermediate of the luminol chemiluminescence reaction, which has a cyclic diazodicarboxamide structure in common with PTAD. However, unlike PTAD, the luminol derivative selectively reacts with tyrosine residues without generating an electrophilic by-product. Various heme proteins and enzymes were tested as catalysts for oxidative tyrosine labeling reactions, and it was found that HRP effectively catalyzes the oxidative activation of luminol derivatives and induces tyrosine-specific modifications (Figure 2). Through the structure-activity relationship studies of luminol derivatives as tyrosine labeling agents, we revealed that $N$-methylated luminol derivatives labeled tyrosine residues efficiently, instead of showing chemiluminescent properties. The redox potential of activated HRP $(\sim 1.1 \mathrm{~V})$ is sufficient to activate SET reactions between compound I (Figure 1) and N-methylated luminol derivatives, resulting in a radical activation labeling agent. Tyrosine residues in proteins and peptides were selectively and efficiently labeled with $N$-methylated luminol derivatives under HRP-activated conditions.

(a)<smiles>[R]c1ccc(-n2c(=O)[nH]n(-c3cc(C[Al])ccc3O)c2=O)cc1</smiles><smiles>[R]c1ccc(N=C=O)cc1</smiles>

(b)<smiles></smiles>

Figure 2. Tyrosine labeling with PTAD and N-methylated luminol derivatives. (a) Tyrosine labeling with PTAD and side reaction with amine group via isocyanate generation. (b) Tyrosine labeling with $N$-methylated luminol derivative in the presence of $\mathrm{HRP}$ and $\mathrm{H}_{2} \mathrm{O}_{2}$.

\section{Peroxidase-Proximity Protein Labeling}

Radical protein labeling using peroxidase has been employed in various applications in biological research. In general, the biomimetic radical reaction proceeds selectively in close proximity to the catalyst because of the short lifetime of the generated radical species. This concept is called 
proximity-dependent labeling (PDL). PDL catalyzed by HRP bound on the secondary antibody is also used as a signal amplification method (tyramide signal amplification-TSA) for immunostaining in biochemistry [45]. Although several signal amplification methods have been reported [46-50], TSA using HRP and tyramide derivatives is the most widely used. The generated tyramide radical reacts with amino acid residues such as tyrosine, tryptophan, histidine, and cysteine [51,52], in close proximity to HRP [53]. We found the novel signal amplification agent $N^{\prime}$-acyl- $N$-methylphenylenediamine instead of tyramide, and revealed that it could be applied to signal amplification using HRP with comparable efficiency to tyramide (Figure 3) [54].

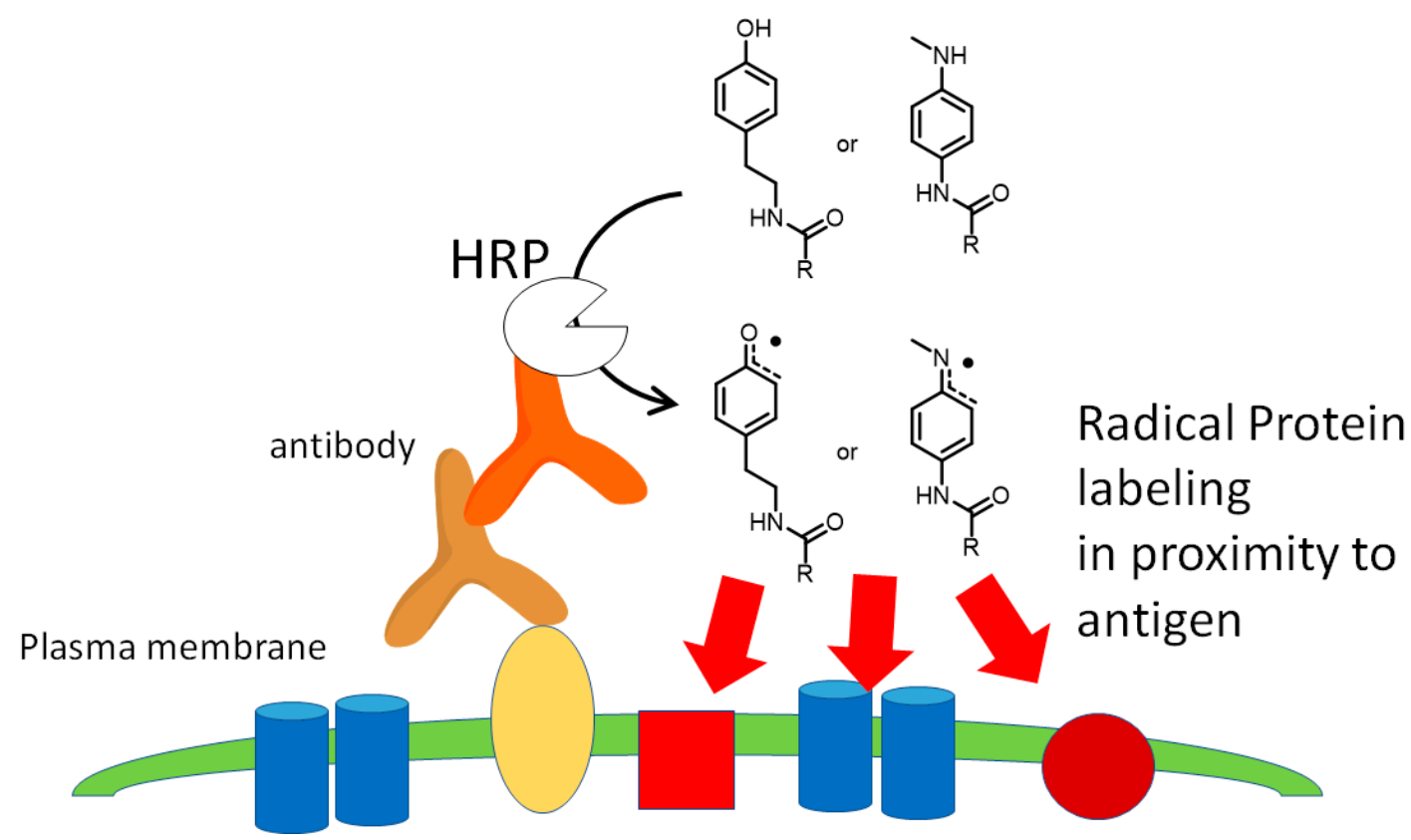

Figure 3. Immunohistochemical signal amplification using HRP-proximity protein labeling. Tyramide and $N^{\prime}$-acyl- $N$-methylphenylenediamine were reported as HRP-proximity protein labeling agents.

PDL has also been applied to the analysis of protein-protein interactions. Methods using HRP have been reported, including selective proteomic proximity labeling assay using tyramide (SPPLAT) [53] and enzyme-mediated activation of radical sources (EMARS) [55]. With SPPLAT, proteins on the cell membrane can be labeled with biotin-tyramide using HRP-conjugated antibodies or HRP-conjugated ligands (e.g., HRP-transferrin). Membrane proteins labeled by proximity labeling can be enriched by streptavidin beads capture. Enriched proteins are identified by MS/MS analysis. Li and co-workers labeled membrane proteins using the SPPLAT method targeting the B cell receptor (BCR) and succeeded in identifying not only known proteins that interact with BCR but also proteins whose interactions were unknown [53]. EMARS is a method that uses biotin-aryl azide as the labeling agent. HRP activates aryl azide to produce short-lived aryl nitrene. Nitrenes are known to react with various amino acid residues, such as tyrosine, tryptophan, lysine, threonine, isoleucine, and proline [56]. Honke and co-workers demonstrated that many kinds of receptor tyrosine kinases (RTKs) formed clusters with beta-integrin by a combination of the EMARS method and antibody array analysis [55].

The labeling radius from HRP by these methods ranges from less than $200 \mathrm{~nm}$ to $300 \mathrm{~nm}[53,55]$, which is suitable for analyzing protein clusters on cell membranes. However, HRP is inactive when expressed in mammalian cytosol. Considering that disulfide bonds and $\mathrm{Ca}^{2+}$ binding sites in the structure of HRP are not formed under intracellular reducing conditions and a $\mathrm{Ca}^{2+}$-scarce environment, Ting and co-workers focused on ascorbate peroxidase that lacks a disulfide bond and a $\mathrm{Ca}^{2+}$ binding site, and developed an engineered ascorbate peroxidase (APEX) that functions as peroxidase even in an intracellular environment [57]. In an intracellular environment, APEX catalyzes the generation of 
tyramide radical. The tyramide radical is short-lived ( $<1 \mathrm{~ms})$ [58] and has a labeling radius of less than $20 \mathrm{~nm}[59,60]$ in the cells (Figure 4).

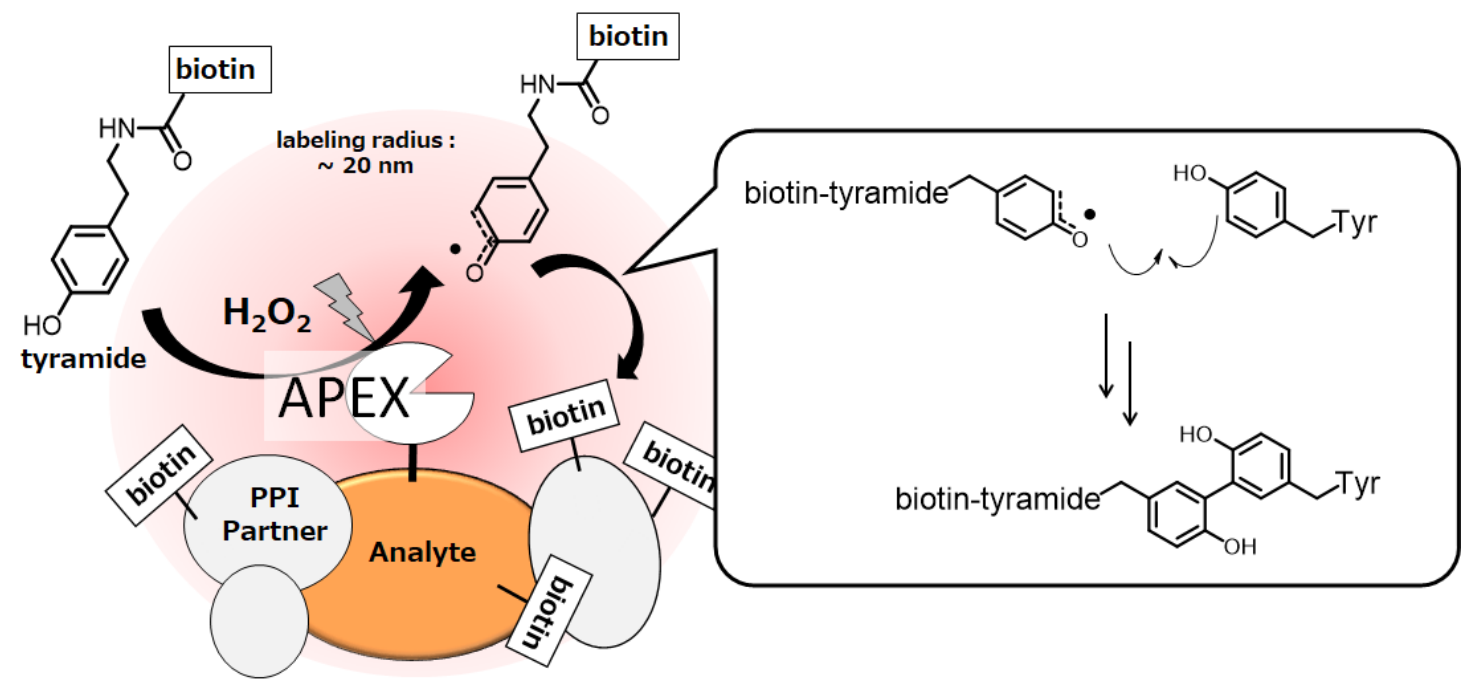

Figure 4. Ascorbate peroxidase (APEX) -proximity labeling of endogenous proteins in living cells.

Ting and co-workers established a method for comprehensively labeling and identifying proteins expressed in specific organelles by fusing APEX to proteins expressed in specific organelles [52]. Furthermore, they developed APEX2, which showed much higher peroxidase activity than APEX among $10^{6}$ APEX mutants by the yeast-display evolution technique [61].

APEX2 has attracted much attention as a powerful tool for protein interaction analysis, and its applications include revealing proteomes in subcellular compartments [51,52,62-65], G-protein-coupled receptor complexes [66,67], subcellular transcriptome mapping [68,69], and APEX2-proximity RNA labeling [70,71].

\section{Protein Labeling Using Photocatalyst}

Not only radical enzymes but also small photocatalysts are used as protein labeling catalysts. Photocatalysts generate reactive oxygen species (ROS) and catalyze SET reactions in response to light stimulus [72]. Utilizing the SET mechanism, Noël and co-workers reported cysteine labeling using eosin Y and aryldiazonium salt [73], and Molander and co-workers reported a method that uses Ni/ruthenium photocatalyst and arylbromide [74]. MacMillan and co-workers developed a photocatalyst-mediated C-terminal labeling technique [23]. They focused on the redox potential of the carboxylic acid structures contained in the protein structure and hypothesized that the carboxyl group at the C-terminus would be selectively activated. The $\mathrm{E}_{1 / 2}$ red value of the carboxyl group in aspartic acid and glutamic acid residues is $\sim 1.25 \mathrm{~V}$ (vs. saturated calomel electrode (SCE)), whereas the $\mathrm{E}_{1 / 2}$ red value of the C-terminal carboxyl group that exists at a single site in the protein sequence is $\sim 0.95 \mathrm{~V}$ (vs. SCE). Slightly acidic reaction conditions ( $\mathrm{pH} 3.5)$ are required in order to achieve efficient conversion, but the selective labeling of the C-terminus proceeded in the presence of aspartic acid and glutamic acid residues. MacMillan and co-workers tuned the reactivity of the Michael acceptor, a labeling agent, so that the labeling reaction with nucleophilic amino acid residues (lysine, serine, threonine, and histidine) would not proceed. The proposed reaction mechanism is shown in Figure 5. Flavin photocatalyst 1 is excited by visible light and undergoes subsequent intersystem crossing (quantum yield $\Phi_{\text {ISC }}=0.38$ for flavin in water at $\mathrm{pH} 7$ ) and conversion into triplet-excited state 2 . Triplet-excited flavin is a strong single-electron oxidant $\left(\mathrm{E}_{1 / 2}{ }^{\text {red }}=1.5 \mathrm{~V}\right.$ vs. SCE in water) and should undergo facile SET with C-terminal carboxylate. Subsequent loss of $\mathrm{CO}_{2}$ from 4 furnishes nitrogen atom stabilized carbon-centered radical 5. Radical 5 reacts with Michael acceptor 6 to produce carbonyl $\alpha$-radical 7. 
The photocatalyst in the radical anion state 3 reduces radical 7 to give product 8 , and regenerates ground-state photocatalyst 1.<smiles></smiles><smiles>CCCCCCCCCCCCC</smiles><smiles>[R]n1c2nc(=O)[nH]c(=O)c-2nc2cc(C)c(C)cc21</smiles><smiles>C1CC1CC1CC1</smiles>

1

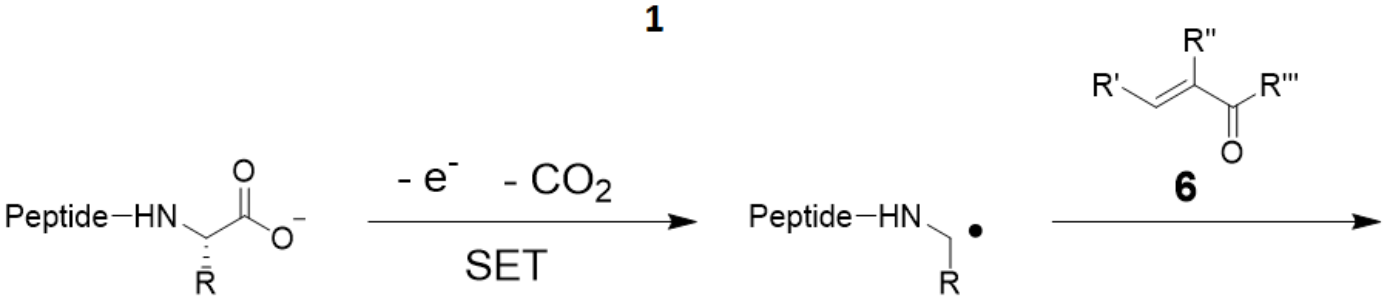

4<smiles></smiles>

7

\section{5}

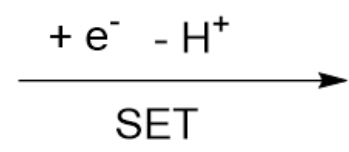

SET

Figure 5. Proposed reaction mechanism for C-terminal labeling with flavin photocatalyst.

Shi and co-workers reported a SET-mediated tryptophan modification at the $\beta$-position through $\mathrm{C}-\mathrm{H}$ activation using $\operatorname{Ir}\left[\mathrm{dF}\left(\mathrm{CF}_{3}\right) \mathrm{ppy}\right]_{2}(\mathrm{dtbbpy})$ complex as the photocatalyst [75]. They proposed a possible mechanism as shown in Figure 6. SET of the indole nitrogen atom generates radical cation 13. The benzylic proton ( $\beta$-position) of the tryptophan can be extracted by a base $\left(\mathrm{K}_{2} \mathrm{HPO}_{4}\right)$ to form 14, and subsequent electron transfer results to form more stable tryptophan radical 15. The mechanism of generating $\mathrm{N}$ radicals by the dehydrogenation of indole $\mathrm{NH}$ from $\mathbf{1 3}$ can also be considered, but the $\beta$-position radical 15 contributes to the reaction. Radical 15 reacts with methyl acrylate 16 to generate another radical, and this is reduced by the iridium catalyst to afford labeled tryptophan product 17. Although the Michael addition reactions with the amine group of lysine and the imidazole of histidine were also observed as side reactions, the modification proceeded selectively at the $\beta$-position of tryptophan and not at the $\beta$-position of tyrosine or phenylalanine in the reaction that used a peptide as the substrate. 


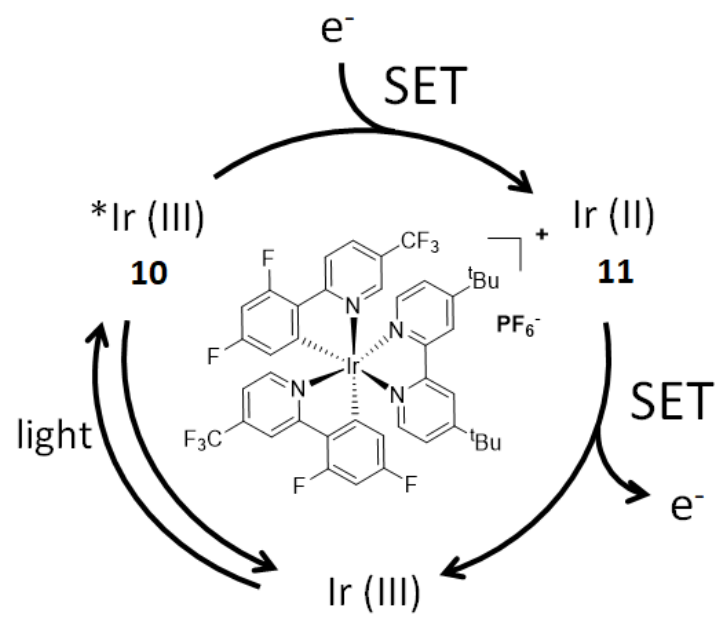

9<smiles>CC(=O)N[C@H](Cc1c[nH]c2ccccc12)C(=O)O</smiles>

12

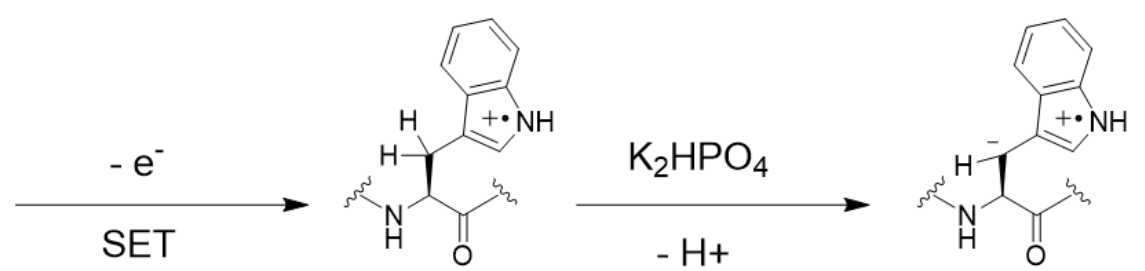

13

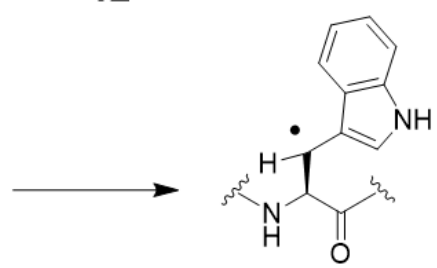

15

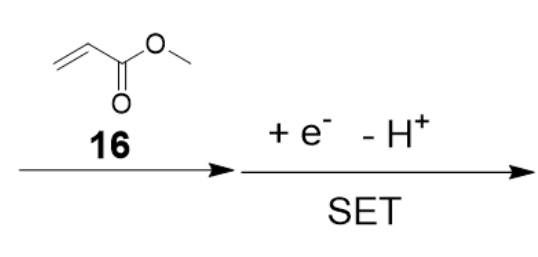

Figure 6. Proposed reaction mechanism for tryptophan $\beta$-position labeling with iridium photocatalyst.

We also developed a tyrosine labeling method that uses $\mathrm{Ru}(\mathrm{bpy})_{3}$ complex and $N^{\prime}$-acyl- $N, N$-dimethyl-1,4-phenylenediamine $\mathbf{2 3}$ as the photoredox catalyst and the labeling agent, respectively [11]. Under visible light irradiation, a stable carbon-carbon bond is formed between the ortho-carbon atom of the phenolic oxygen of the tyrosine residue and the ortho-carbon atom of the phenylenediamine derivative. Regarding the mechanism, in the absence of a labeling agent, ${ }^{1} \mathrm{O}_{2}$ is generated by the catalyst that functions as a photosensitizer. ${ }^{1} \mathrm{O}_{2}$ is involved in the production of $\mathrm{Ru}(\mathrm{III})$ active species 20 . $\mathrm{Ru}(\mathrm{III})$ active species $20(1.1 \mathrm{~V}$ vs. SCE) can abstract a single electron from the tyrosine residue ( $\sim 0.7 \mathrm{~V}$ vs. SCE) [76] and labeling agent 23 ( $0.63 \mathrm{~V}$ vs. SCE) [54]. Radical species 22 or $\mathbf{2 4}$ can react with $\mathbf{2 3}$ or $\mathbf{2 1}$, respectively, to give product $\mathbf{2 5}$ through subsequent oxidation by SET (Figure 7) [77]. 


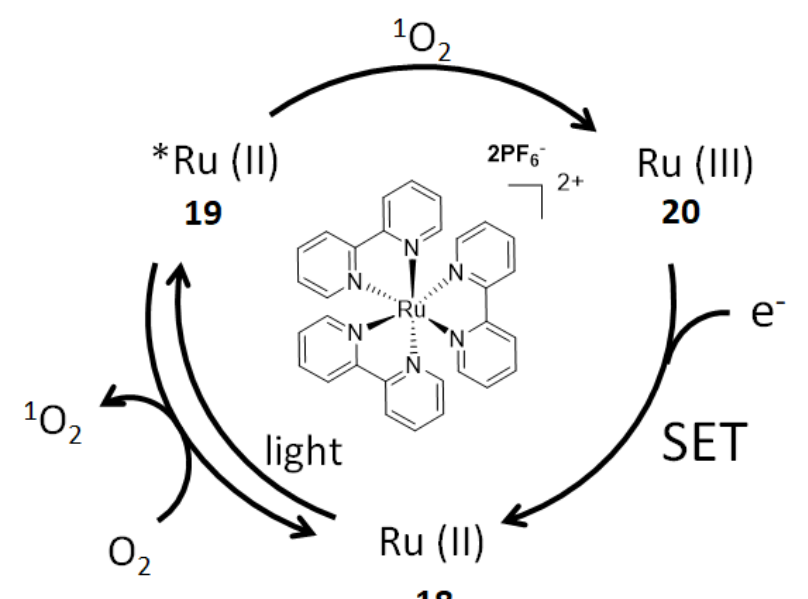

18<smiles>CC(=O)C(Cc1ccc(O)cc1)NC(C)C</smiles>

21<smiles>[R]C(=O)Nc1ccc(N(C)C)cc1</smiles>

23<smiles>CC=CNC(Cc1ccc(C)cc1)C(C)=O</smiles>

22<smiles></smiles>

24

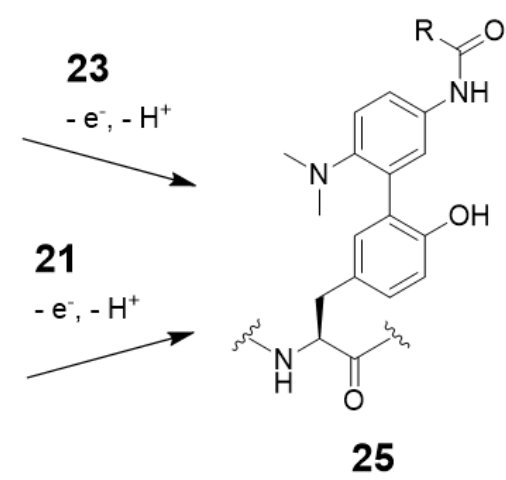

25

Figure 7. Proposed reaction mechanism for tyrosine labeling with ruthenium photocatalyst.

\section{Photocatalyst-Proximity Labeling}

As mentioned in Section 3, photocatalyst-catalyzed radical protein labeling proceeds selectively in close proximity to a catalyst. Using this property, we designed a ligand-conjugated catalyst in which a ligand and a ruthenium catalyst were linked, and using this catalyst, we selectively labeled ligand-binding proteins in a protein mixture. As a proof-of-concept model, benzenesulfonamide-conjugated ruthenium complex $\mathbf{2 6}$ was synthesized for targeting carbonic anhydrase (CA). Mouse erythrocytes were incubated with $\mathbf{2 6}$ and photo-irradiated in the presence of the labeling agent. Despite the presence of various proteins in erythrocytes, CA was selectively labeled [11]. We also synthesized gefitinib-conjugated ruthenium catalyst 27, which targets the epidermal growth factor receptor (EGFR) expressed in A431 cells, and succeeded in the selective labeling of EGFR in A431 cells [77]. Furthermore, we developed a method for target-selective purification and labeling using ruthenium-catalyst-functionalized affinity beads targeting CA and dihydrofolate reductase (DHFR) (Figure 8) [72]. 


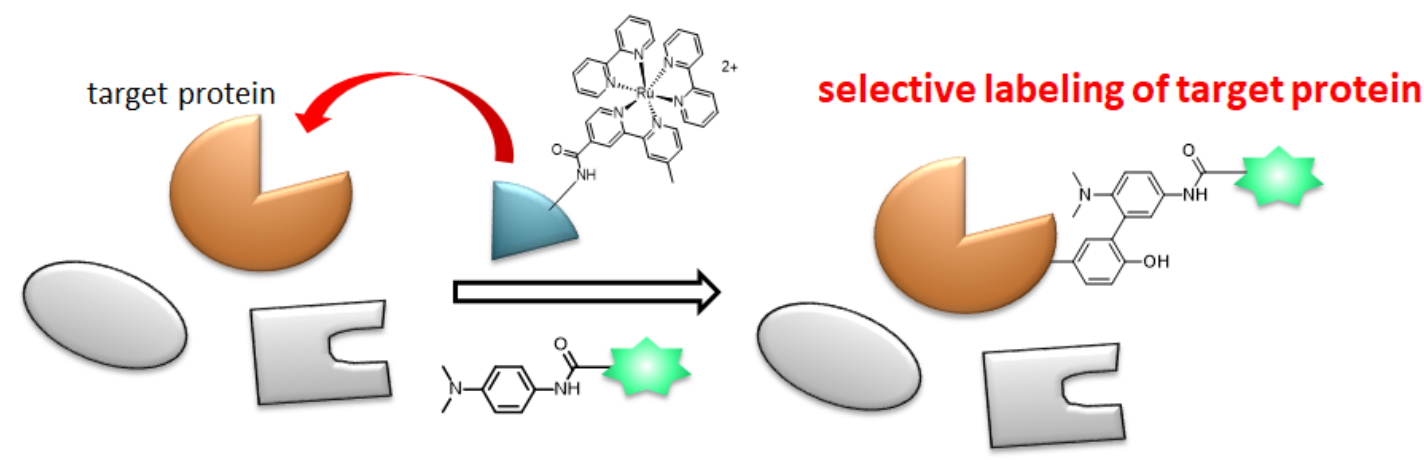

protein mixiture
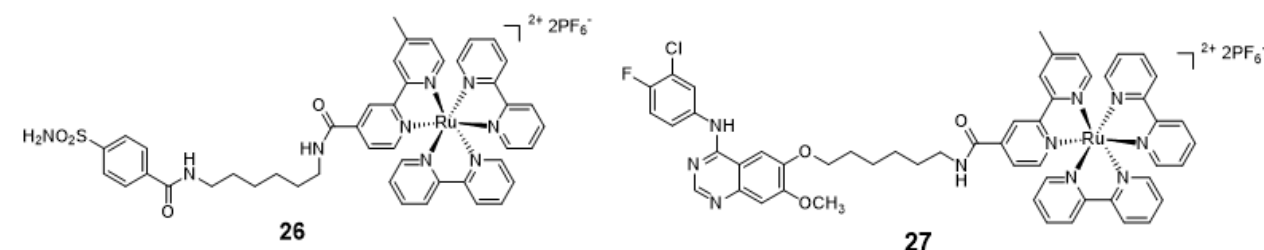

Figure 8. Target selective labeling by proximity labeling using ligand-conjugated photocatalysts $\mathbf{2 6}$ and 27.

In these applications, protein labeling in close proximity to the ruthenium photocatalyst was accomplished using $N^{\prime}$-acyl- $N, N$-dimethyl-1,4-phenylenediamine 23 as the labeling agent. We also found a novel labeling agent that labels efficiently and selectively in nanometer-scale catalyst proximity. Using model substrate $\mathbf{2 8}$, in which a tyrosine residue is linked to a ruthenium photocatalyst, the reaction efficiencies of various labeling agents were evaluated. It was found by LC-MS analysis that 28 was efficiently labeled with 1-methyl-4-aryl-urazole (MAUra, 29) and converted into 30 and 31 (Figure 9). Furthermore, in order to estimate the labeling radius from the ruthenium complex, a ruthenium complex conjugated to tyrosine was synthesized with a rigid proline linker, in which the distance between ruthenium and tyrosine is several nanometers, as shown in Figure 9. MAUra (29) labeled tyrosine when a ruthenium complex and a tyrosine residue were in close proximity, and its distance dependence is not contradicted by the reported SET distance in a physiological environment $(\sim 1.4 \mathrm{~nm})$ [78]. Desthiobiotin-conjugated MAUra 32 was used to selectively label CA in a protein mixture. The CA labeled with 32 was also successfully enriched using streptavidin beads (18.5\% in two steps of labeling and enrichment). Identification of the labeling site by MS revealed that the tyrosine residue closest to the ligand binding site was selectively labeled, suggesting nanometer-scale proximity dependence of MAUra labeling (Figure 10) [12]. 


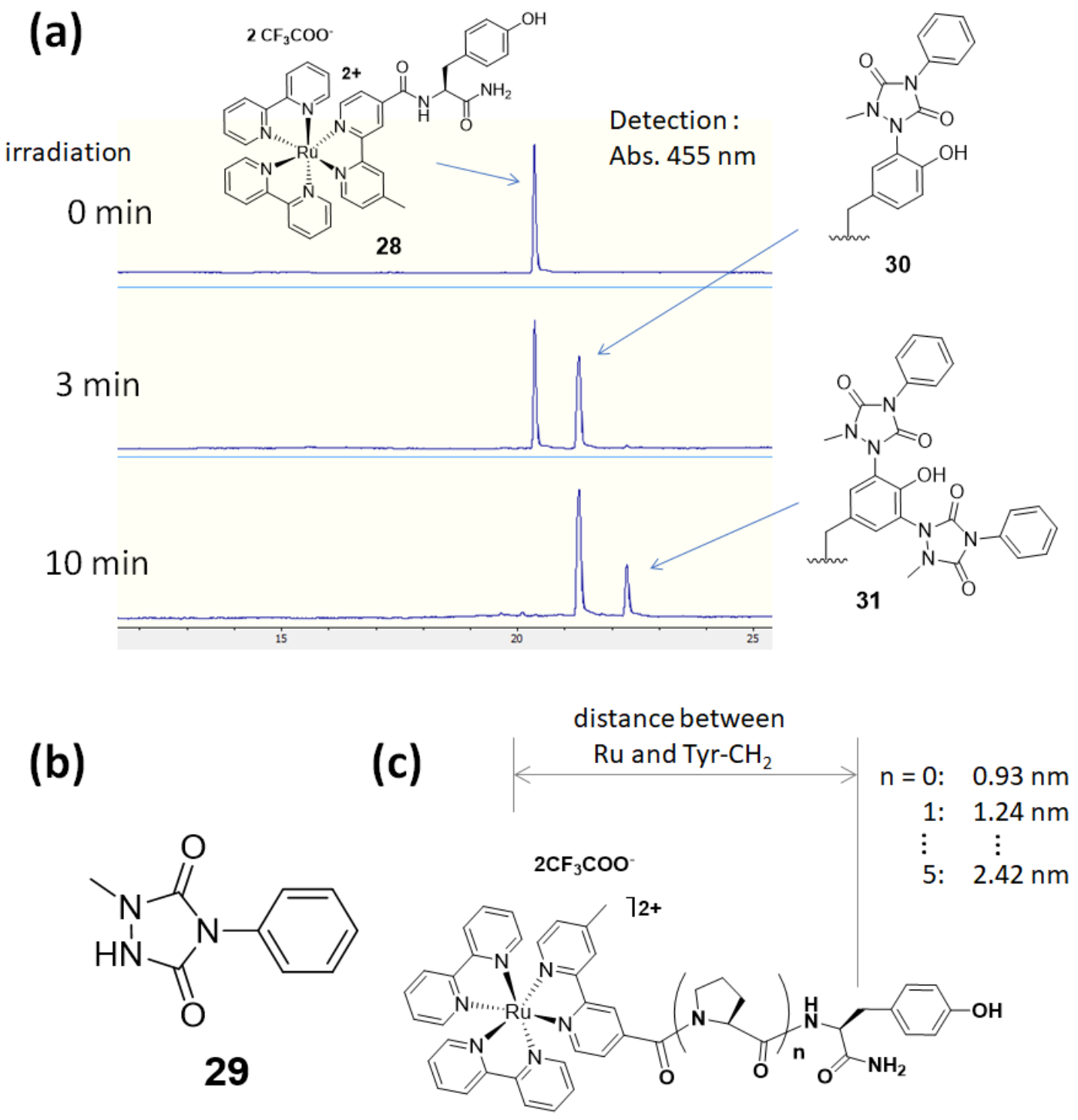

Figure 9. Photocatalyst-proximity tyrosine labeling. (a) Model substrate $\mathbf{2 8}$ was labeled with 29. (b) Structure of labeling agent MAUra 29. (c) Model substrate with a rigid proline linker with a distance of several nanometers between ruthenium and tyrosine. 

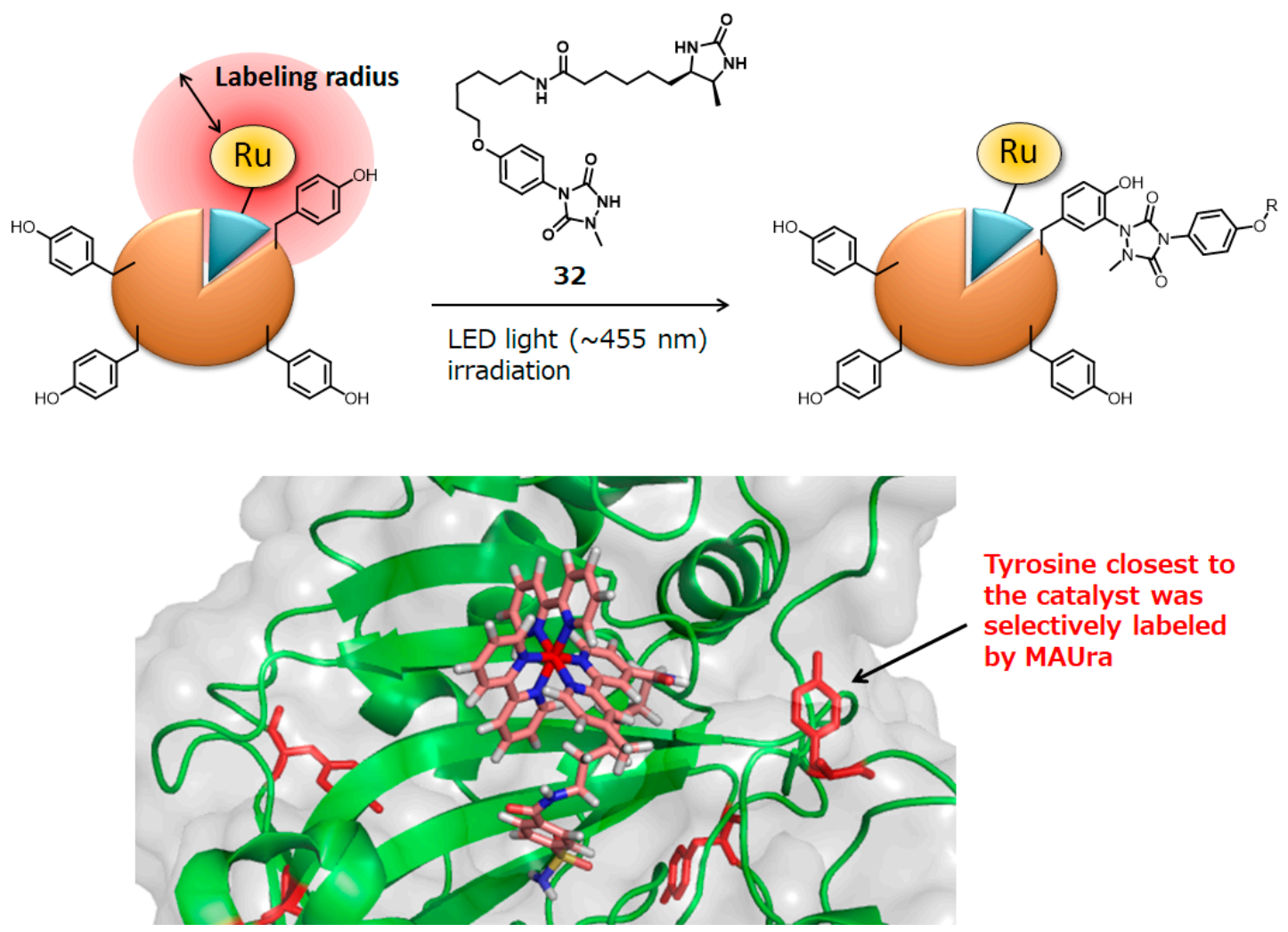

Figure 10. Photocatalyst-proximity labeling with MAUra.

\section{Electrochemical Protein Labeling}

Protein modification using peroxidase or a photocatalyst is suitable for analyzing protein association and protein-protein interactions. However, it is necessary to develop an appropriate protein labeling agent according to the oxidation potential of each catalyst. Moreover, these methods sometimes require the addition of an oxidant, which is often a cause for concern about the oxidative damage of proteins. In recent years, protein labeling methods using electrochemistry have been reported to overcome this disadvantage. At present, electrochemistry is limited to labeling purified proteins, but in the case of electrochemical organic chemistry, the voltage applied to the reaction system can be adjusted easily and the reaction proceeds efficiently even in an aqueous buffer. It can be used for the functionalization of proteins because of its high amino acid residue selectivity and low oxidative damage.

An electrochemical tyrosine-selective modification reaction (e-Y-Click) was reported by Alvarez-Dorta, Boujtita, Gouin, and co-workers (Figure 11) [79]. In this method, phenylurazole 33 is electrochemically oxidized and PTAD (Figures 2 and 11) is gradually produced in the reaction system. Because the PTAD generated by anode oxidation reacts with tyrosine instantaneously, side reactions with nucleophilic residues and $\mathrm{N}$-terminus via isocyanate formation can be suppressed. As phenylurazole undergoes anodic oxidation at $0.36 \mathrm{~V}$ (vs. SCE), peptides and proteins are labeled without severe oxidative damage. Using glucose oxidase (GOx) as the substrate, they confirmed that the enzymatic activity of GOx was not affected by tyrosine labeling through the e-Y-Click reaction. Lei and co-workers also reported tyrosine-selective electrochemical labeling using phenothiazine $\mathbf{3 4}$ as the labeling agent. (Figure 11) [80]. 


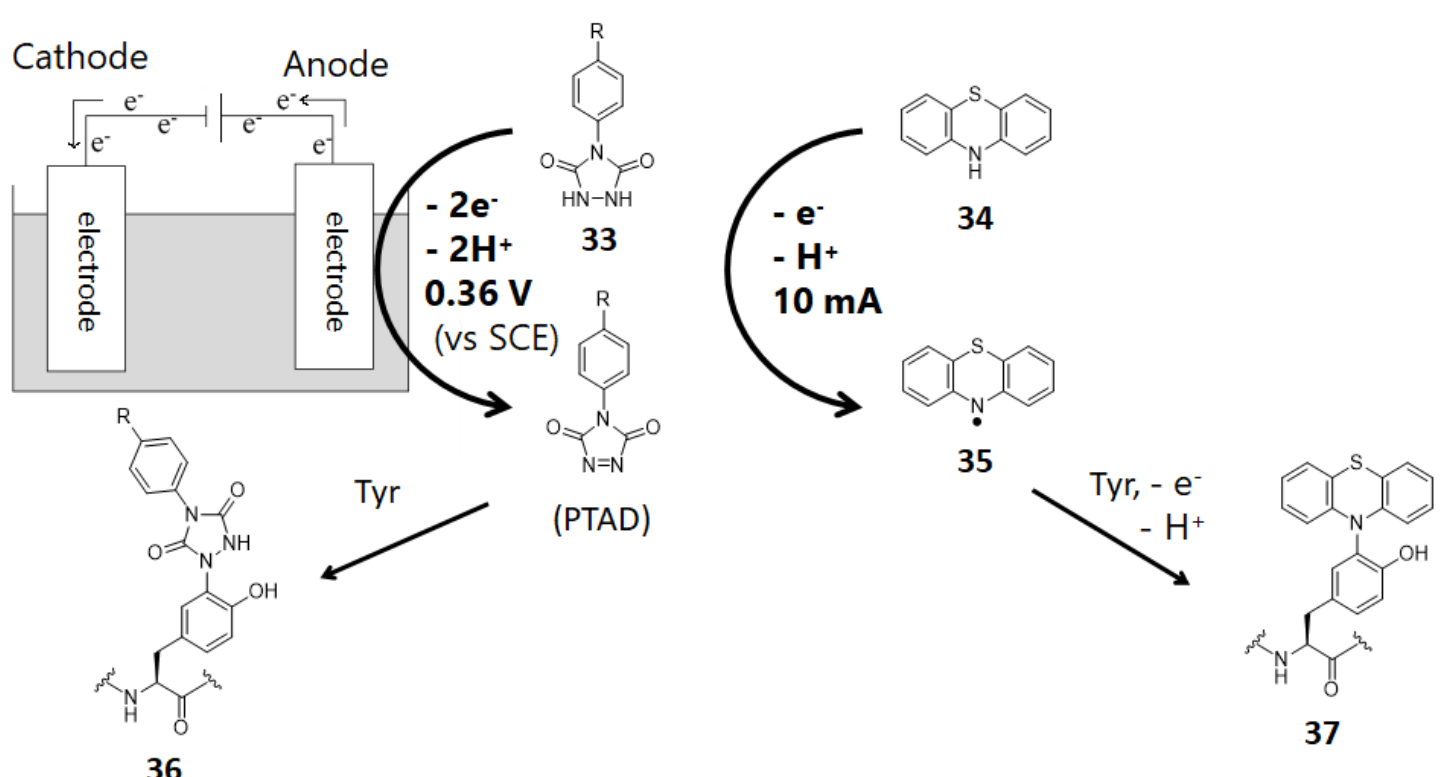

Figure 11. Electrochemical tyrosine labeling. SCE: saturated calomel electrode.

Kanai, Oisaki, and co-workers reported that 9-azabicyclo [3.3.1]nonane-3-one-N-oxyl (keto-ABNO, Figure 12) selectively labels tryptophan residues in the presence of $0.1 \%$ acetic acid and $\mathrm{NaNO}_{2}$ [18]. Although keto-ABNO is oxidized by NOx in this method, they recently reported a method for activating the reaction by electrochemical oxidation [81]. They added 4-oxo-TEMPO as the electrochemical mediator to suppress both the anodic overoxidation of proteins and the cross reactivity to other amino acid residues (Figure 12).

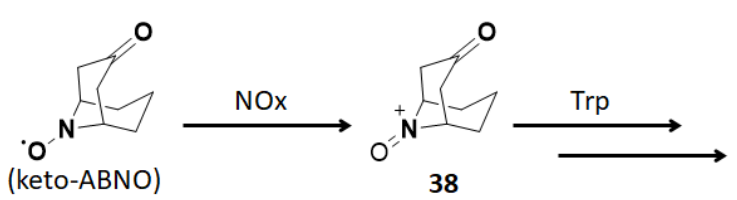

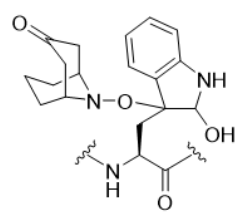

39

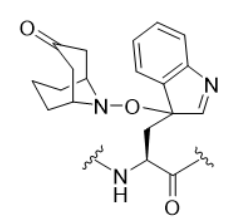

40

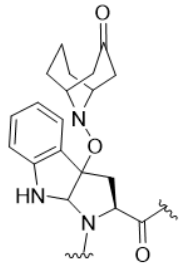

41

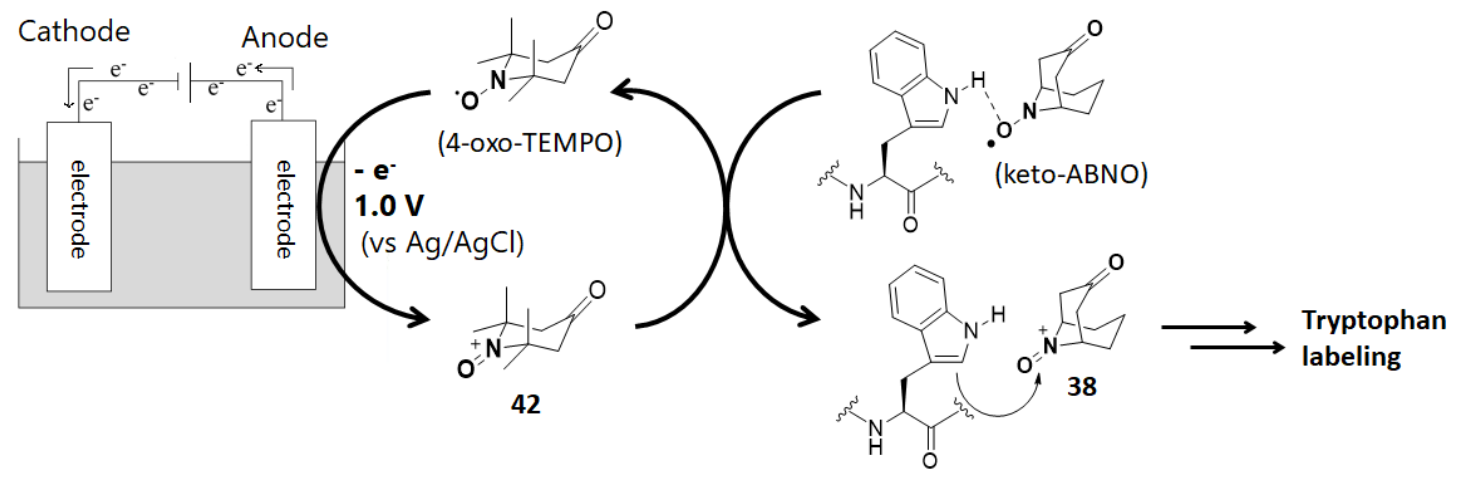

Figure 12. Tryptophan labeling with keto-ABNO and the electrochemical activation of tryptophan labeling.

\section{Conclusions}

In this review, protein labeling methods using biomimetic radical reactions were reviewed. Protein labeling techniques using electrophilic agents have been extensively employed. However, protein labeling targeting other amino acid residues is a challenging and attractive research topic. In recent 
years, in order to resolve several related issues, protein labeling using radical reactions has been actively developed targeting tyrosine and tryptophan residues and the C-terminus. Enzymes, particularly peroxidase, have been utilized as the catalyst for radical protein labeling, and peroxidase-proximity labeling has recently been used as an analytical method for protein association, protein-protein interaction, and transcriptome. In addition, protein modification using photocatalysts has been developed for the target identification of bioactive small molecules, and it is expected in the future to be used in not only the selective modification of target proteins in protein-mixed systems but also proximity labeling in cells. Furthermore, labeling with an electrochemical technique for precise voltage control has recently been developed and will be useful for labeling functional proteins. Table 1 summarizes representative protein labeling methods using biomimetic radical reactions. Future developments in radical protein modification will contribute to research on the elucidation of biological phenomena and drug delivery systems, and protein labeling using radical reactions will be a breakthrough technique in the development of these research areas.

Table 1. Overview of protein labeling methods using biomimetic radical reactions.

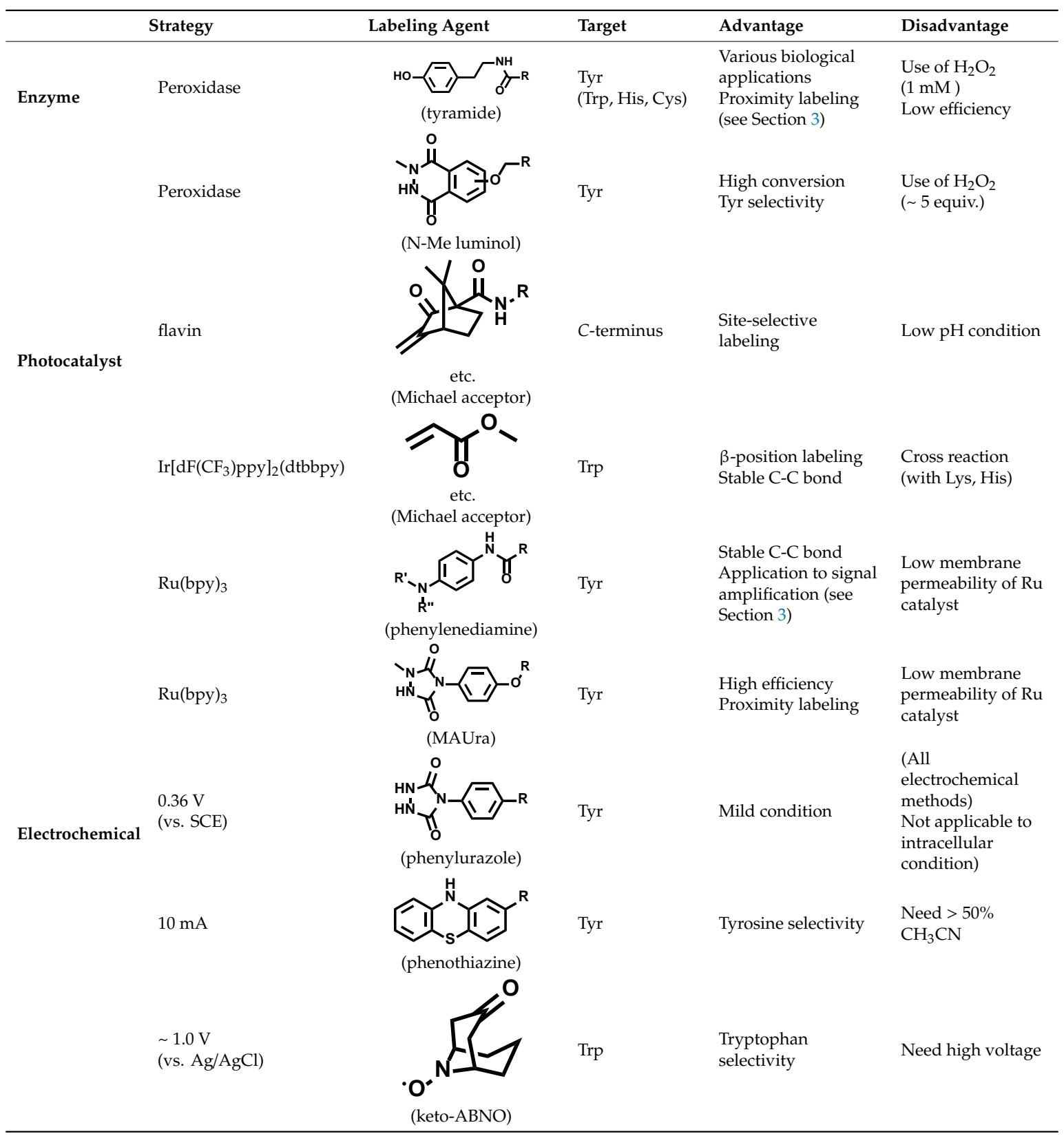


Funding: Financial support in the form of a "Grant-in-Aid for Scientific Research (B) (19H02848 to S. Sato)" and "Chemistry for Multimolecular Crowding Biosystems (18H04542 to H. Nakamura)" from MEXT, Japan is gratefully acknowledged.

Conflicts of Interest: The authors declare no conflict of interest.

\section{References}

1. Krall, N.; Da Cruz, F.P.; Boutureira, O.; Bernardes, G.J.L. Site-selective protein-modification chemistry for basic biology and drug development. Nat. Chem. 2016, 8, 103-113. [CrossRef]

2. Zhang, Y.; Park, K.Y.; Suazo, K.F.; Distefano, M.D. Recent progress in enzymatic protein labelling techniques and their applications. Chem. Soc. Rev. 2018, 47, 9106-9136. [CrossRef]

3. Seim, K.L.; Obermeyer, A.C.; Francis, M.B. Oxidative Modification of Native Protein Residues Using Cerium(IV) Ammonium Nitrate. J. Am. Chem. Soc. 2011, 133, 16970-16976. [CrossRef]

4. Hooker, J.M.; Kovacs, E.W.; Francis, M.B. Interior Surface Modification of Bacteriophage MS2. J. Am. Chem. Soc. 2004, 126, 3718-3719. [CrossRef]

5. Joshi, N.S.; Whitaker, L.R.; Francis, M.B. A three-component Mannich-type reaction for selective tyrosine bioconjugation. J. Am. Chem. Soc. 2004, 126, 15942-15943. [CrossRef]

6. Tilley, S.D.; Francis, M.B. Tyrosine-selective protein alkylation using $\pi$-allylpalladium complexes. J. Am. Chem. Soc. 2006, 128, 1080-1081. [CrossRef] [PubMed]

7. Schlick, T.L.; Ding, Z.; Kovacs, E.W.; Francis, M.B. Dual-surface modification of the tobacco mosaic virus. J. Am. Chem. Soc. 2005, 127, 3718-3723. [CrossRef] [PubMed]

8. Struck, A.W.; Bennett, M.R.; Shepherd, S.A.; Law, B.J.C.; Zhuo, Y.; Wong, L.S.; Micklefield, J. An Enzyme Cascade for Selective Modification of Tyrosine Residues in Structurally Diverse Peptides and Proteins. J. Am. Chem. Soc. 2016, 138, 3038-3045. [CrossRef] [PubMed]

9. Ohata, J.; Miller, M.K.; Mountain, C.M.; Vohidov, F.; Ball, Z.T. A Three-Component Organometallic Tyrosine Bioconjugation. Angew. Chemie Int. Ed. 2018, 57, 2827-2830. [CrossRef] [PubMed]

10. Ban, H.; Gavrilyuk, J.; Barbas, C.F. Tyrosine Bioconjugation through Aqueous Ene-Type Reactions: A Click-Like Reaction for Tyrosine. J. Am. Chem. Soc. 2010, 132, 1523-1525. [CrossRef] [PubMed]

11. Sato, S.; Nakamura, H. Ligand-directed selective protein modification based on local single-electron-transfer catalysis. Angew. Chemie Int. Ed. 2013, 52, 8681-8684. [CrossRef] [PubMed]

12. Sato, S.; Hatano, K.; Tsushima, M.; Nakamura, H. 1-Methyl-4-aryl-urazole (MAUra) labels tyrosine in proximity to ruthenium photocatalysts. Chem. Commun. 2018, 54, 5871-5874. [CrossRef] [PubMed]

13. Antos, J.M.; Francis, M.B. Selective tryptophan modification with rhodium carbenoids in aqueous solution. J. Am. Chem. Soc. 2004, 126, 10256-10257. [CrossRef] [PubMed]

14. Ruiz-Rodriguez, J.; Albericio, F.; Lavilla, R. Postsynthetic modification of peptides: Chemoselective C-arylation of tryptophan residues. Chem. A Eur. J. 2010, 16, 1124-1127. [CrossRef] [PubMed]

15. Popp, B.V.; Ball, Z.T. Proximity-driven metallopeptide catalysis: Remarkable side-chain scope enables modification of the Fos bZip domain. Chem. Sci. 2011, 2, 690. [CrossRef]

16. Williams, T.J.; Reay, A.J.; Whitwood, A.C.; Fairlamb, I.J.S. A mild and selective Pd-mediated methodology for the synthesis of highly fluorescent 2-arylated tryptophans and tryptophan-containing peptides: A catalytic role for Pd0 nanoparticles? Chem. Commun. 2014, 50, 3052-3054. [CrossRef] [PubMed]

17. Hansen, M.B.; Hubálek, F.; Skrydstrup, T.; Hoeg-Jensen, T. Chemo- and Regioselective Ethynylation of Tryptophan-Containing Peptides and Proteins. Chem. A Eur. J. 2016, 22, 1572-1576. [CrossRef]

18. Seki, Y.; Ishiyama, T.; Sasaki, D.; Abe, J.; Sohma, Y.; Oisaki, K.; Kanai, M. Transition Metal-Free Tryptophan-Selective Bioconjugation of Proteins. J. Am. Chem. Soc. 2016, 138, 10798-10801. [CrossRef]

19. Lin, S.; Yang, X.; Jia, S.; Weeks, A.M.; Hornsby, M.; Lee, P.S.; Nichiporuk, R.V.; Iavarone, A.T.; Wells, J.A.; Toste, F.D.; et al. Redox-based reagents for chemoselective methionine bioconjugation. Science 2017, 355 , 597-602. [CrossRef]

20. Taylor, M.T.; Nelson, J.E.; Suero, M.G.; Gaunt, M.J. A protein functionalization platform based on selective reactions at methionine residues. Nature 2018, 562, 563-568. [CrossRef]

21. Obermeyer, A.C.; Jarman, J.B.; Francis, M.B. N-Terminal Modi fi cation of Proteins with o-Aminophenols. J. Am. Chem. Soc. 2014. [CrossRef] [PubMed] 
22. Rosen, C.B.; Francis, M.B. Targeting the $\mathrm{N}$ terminus for site-selective protein modification. Nat. Chem. Biol. 2017, 13, 697-705. [CrossRef] [PubMed]

23. Bloom, S.; Liu, C.; Kölmel, D.K.; Qiao, J.X.; Zhang, Y.; Poss, M.A.; Ewing, W.R.; MacMillan, D.W.C. Decarboxylative alkylation for site-selective bioconjugation of native proteins via oxidation potentials. Nat. Chem. 2018, 10, 205-211. [CrossRef] [PubMed]

24. Le Caër, S. Water Radiolysis: Influence of Oxide Surfaces on H2 Production under Ionizing Radiation. Water 2011, 3, 235-253. [CrossRef]

25. DiMarco, T.; Giulivi, C. Current Analytical Methods for the Detection of Dityrosine, a Biomarker of Oxidative Stress, in Biological Samples. Mass Spectrom Rev 2007, 26, 108-120. [CrossRef] [PubMed]

26. Houée-Lévin, C.; Bobrowski, K.; Horakova, L.; Karademir, B.; Schöneich, C.; Davies, M.J.; Spickett, C.M. Exploring oxidative modifications of tyrosine: An update on mechanisms of formation, advances in analysis and biological consequences. Free Radic. Res. 2015, 49, 347-373. [CrossRef]

27. Fancy, D.A.; Melcher, K.; Johnston, S.A.; Kodadek, T. New chemistry for the study of multiprotein complexes: The six- histidine tag as a receptor for a protein crosslinking reagent. Chem. Biol. 1996, 3, 551-559. [CrossRef]

28. Meunier, S.; Strable, E.; Finn, M.G. Crosslinking of and Coupling to Viral Capsid Proteins by Tyrosine Oxidation. Chem. Biol. 2004, 11, 319-326. [CrossRef]

29. Lewandowski, A.T.; Small, D.A.; Chen, T.; Payne, G.F.; Bentley, W.E. Tyrosine-based "activatable pro-tag": Enzyme-catalyzed protein capture and release. Biotechnol. Bioeng. 2006, 93, 1207-1215. [CrossRef]

30. Lewandowski, A.T.; Yi, H.; Luo, X.; Payne, G.F.; Ghodssi, R.; Rubloff, G.W.; Bentley, W.E. Protein assembly onto patterned microfabricated devices through enzymatic activation of fusion pro-tag. Biotechnol. Bioeng. 2008, 99, 499-507. [CrossRef]

31. Wu, H.C.; Shi, X.W.; Tsao, C.Y.; Lewandowski, A.T.; Fernandes, R.; Hung, C.W.; DeShong, P.; Kobatake, E.; Valdes, J.J.; Payne, G.F.; et al. Biofabrication of antibodies and antigens via IgG-binding domain engineered with activatable pentatyrosine pro-tag. Biotechnol. Bioeng. 2009, 103, 231-240. [CrossRef] [PubMed]

32. Mattinen, M.L.; Kruus, K.; Buchert, J.; Nielsen, J.H.; Andersen, H.J.; Steffensen, C.L. Laccase-catalyzed polymerization of tyrosine-containing peptides. FEBS J. 2005, 272, 3640-3650. [CrossRef] [PubMed]

33. Mattinen, M.L.; Hellman, M.; Permi, P.; Autio, K.; Kalkkinen, N.; Buchert, J. Effect of protein structure on laccase-catalyzed protein oligomerization. J. Agric. Food Chem. 2006, 54, 8883-8890. [CrossRef] [PubMed]

34. Gross, A.J.; Sizer, I.W. The oxidation of tyramine, tyrosine, and related compounds by peroxidase. J. Biol. Chem. 1959, 234, 1611-1614. [PubMed]

35. Matheis, G.; Whitaker, J.R. Peroxidase-catalyzed cross linking of proteins. J. Protein Chem. 1984, 3, 35-48. [CrossRef]

36. Jacob, J.S.; Cistola, D.P.; Hsu, F.F.; Muzaffar, S.; Mueller, D.M.; Hazen, S.L.; Heinecke, J.W. Human phagocytes employ the myeloperoxidase-hydrogen peroxide system to synthesize dityrosine, trityrosine, pulcherosine, and isodityrosine by a tyrosyl radical-dependent pathway. J. Biol. Chem. 1996, 271, 19950-19956. [CrossRef]

37. Malencik, D.A.; Anderson, S.R. Dityrosine formation in calmodulin: Cross-linking and polymerization catalyzed by Arthromyces peroxidase. Biochemistry 1996, 35, 4375-4386. [CrossRef]

38. Michon, T.; Chenu, M.; Kellershon, N.; Desmadril, M.; Guéguen, J. Horseradish peroxidase oxidation of tyrosine-containing peptides and their subsequent polymerization: A kinetic study. Biochemistry 1997, 36, 8504-8513. [CrossRef]

39. Oudgenoeg, G.; Hilhorst, R.; Piersma, S.R.; Boeriu, C.G.; Gruppen, H.; Hessing, M.; Voragen, A.G.J.; Laane, C. Peroxidase-mediated cross-linking of a tyrosine-containing peptide with ferulic acid. J. Agric. Food Chem. 2001, 49, 2503-2510. [CrossRef]

40. Minamihata, K.; Goto, M.; Kamiya, N. Site-specific protein cross-linking by peroxidase-catalyzed activation of a tyrosine-containing peptide tag. Bioconjug. Chem. 2011, 22, 74-81. [CrossRef]

41. Kersten, P.J.; Kalyanaraman, B.; Hammel, K.E.; Reinhammar, B.; Kirk, T.K. Comparison of lignin peroxidase, horseradish peroxidase and laccase in the oxidation of methoxybenzenes. Biochem. J. 1990, 268, 475-480. [CrossRef] [PubMed]

42. Ban, H.; Nagano, M.; Gavrilyuk, J.; Hakamata, W.; Inokuma, T.; Barbas, C.F. Facile and Stabile Linkages through Tyrosine: Bioconjugation Strategies with the Tyrosine-Click Reaction. Bioconjug. Chem. 2013, 24, 520-532. [CrossRef] [PubMed]

43. Sato, S.; Nakamura, K.; Nakamura, H. Tyrosine-Specific Chemical Modification with in Situ Hemin-Activated Luminol Derivatives. ACS Chem. Biol. 2015, 10, 2633-2640. [CrossRef] [PubMed] 
44. Sato, S.; Nakamura, K.; Nakamura, H. Horseradish-Peroxidase-Catalyzed Tyrosine Click Reaction. ChemBioChem 2017, 18, 475-478. [CrossRef] [PubMed]

45. Bobrow, M.N.; Shaughnessy, K.J.; Litt, G.J. Catalyzed reporter deposition, a novel method of signal amplification. II. Application to membrane immunoassays. J. Immunol. Methods 1991, 137, 103-112. [CrossRef]

46. Hsu, S.-M.; Raine, L.; Fange, H. Use of Avidin-Biotin-Peroxidase Immunoperoxidase Techniques: A Comparison Complex ( ABC ) in between Unlabeled Antibody ( PAP ). J. Histochem. Histochem. Cytochem. 1981, 29, 577-580. [CrossRef]

47. Toda, Y.; Kono, K.; Abiru, H.; Kokuryo, K.; Endo, M.; Yaegashi, H.; Fukumoto, M. Application of tyramide signal amplification system to immunohistochemistry: A potent method to localize antigens that are not detectable by ordinary method. Pathol. Int. 1999, 49, 479-483. [CrossRef]

48. Pham, X.H.; Hahm, E.; Kim, T.H.; Kim, H.M.; Lee, S.H.; Lee, Y.S.; Jeong, D.H.; Jun, B.H. Enzyme-catalyzed Ag Growth on Au Nanoparticle-assembled Structure for Highly Sensitive Colorimetric Immunoassay. Sci. Rep. 2018, 8, 1-7. [CrossRef]

49. Polaske, N.W.; Kelly, B.D.; Ashworth-Sharpe, J.; Bieniarz, C. Quinone Methide Signal Amplification: Covalent Reporter Labeling of Cancer Epitopes using Alkaline Phosphatase Substrates. Bioconjug. Chem. 2016, 27, 660-666. [CrossRef]

50. Lee, J.; Song, E.K.; Bae, Y.; Min, J.; Rhee, H.W.; Park, T.J.; Kim, M.; Kang, S. An enhanced ascorbate peroxidase 2/antibody-binding domain fusion protein (APEX2-ABD) as a recombinant target-specific signal amplifier. Chem. Commun. 2015, 51, 10945-10948. [CrossRef]

51. Hung, V.; Zou, P.; Rhee, H.W.; Udeshi, N.D.; Cracan, V.; Svinkina, T.; Carr, S.A.; Mootha, V.K.; Ting, A.Y. Proteomic Mapping of the Human Mitochondrial Intermembrane Space in Live Cells via Ratiometric APEX Tagging. Mol. Cell 2014, 55, 332-341. [CrossRef] [PubMed]

52. Rhee, H.W.; Zou, P.; Udeshi, N.D.; Martell, J.D.; Mootha, V.K.; Carr, S.A.; Ting, A.Y. Proteomic mapping of mitochondria in living cells via spatially restricted enzymatic tagging. Science 2013, 339, 1328-1331. [CrossRef] [PubMed]

53. Rees, J.S.; Li, X.W.; Perrett, S.; Lilley, K.S.; Jackson, A.P. Selective proteomic proximity labeling assay using tyramide (SPPLAT): A quantitative method for the proteomic analysis of localized membrane-bound protein clusters. Curr. Protoc. Protein Sci. 2015, 2015, 19.27.1-19.27.18.

54. Sato, S.; Yoshida, M.; Hatano, K.; Matsumura, M.; Nakamura, H. N'-acyl-N-methylphenylenediamine as a novel proximity labeling agent for signal amplification in immunohistochemistry. Bioorganic Med. Chem. 2019, 27, 1110-1118. [CrossRef]

55. Kotani, N.; Gu, J.; Isaji, T.; Udaka, K.; Taniguchi, N.; Honke, K. Biochemical visualization of cell surface molecular clustering in living cells. Proc. Natl. Acad. Sci. USA 2008, 105, 7405-7409. [CrossRef]

56. Kotzyba-Hibert, F.; Kapfer, I.; Goeldner, M. Recent Trends in Photoaffinity Labeling. Angew. Chemie Int. Ed. English 1995, 34, 1296-1312. [CrossRef]

57. Martell, J.D.; Deerinck, T.J.; Sancak, Y.; Poulos, T.L.; Mootha, V.K.; Sosinsky, G.E.; Ellisman, M.H.; Ting, A.Y. Engineered ascorbate peroxidase as a genetically encoded reporter for electron microscopy. Nat. Biotechnol. 2012, 30, 1143-1148. [CrossRef]

58. Mortensen, A.; Skibsted, L.H. Importance of Carotenoid Structure in Radical-Scavenging Reactions. J. Agric. Food Chem. 1997, 45, 2970-2977. [CrossRef]

59. Mayer, G.; Bendayan, M. Biotinyl-tyramide: A novel approach for electron microscopic immunocytochemistry. J. Histochem. Cytochem. 1997, 45, 1449-1454. [CrossRef]

60. Chen, C.L.; Hu, Y.; Udeshi, N.D.; Lau, T.Y.; Wirtz-Peitz, F.; He, L.; Ting, A.Y.; Carr, S.A.; Perrimon, N. Proteomic mapping in live Drosophila tissues using an engineered ascorbate peroxidase. Proc. Natl. Acad. Sci. USA 2015, 112, 12093-12098. [CrossRef]

61. Lam, S.S.; Martell, J.D.; Kamer, K.J.; Deerinck, T.J.; Ellisman, M.H.; Mootha, V.K.; Ting, A.Y. Directed evolution of APEX2 for electron microscopy and proximity labeling. Nat. Methods 2015, 12, 51-54. [CrossRef] [PubMed]

62. Han, S.; Udeshi, N.D.; Deerinck, T.J.; Svinkina, T.; Ellisman, M.H.; Carr, S.A.; Ting, A.Y. Proximity Biotinylation as a Method for Mapping Proteins Associated with mtDNA in Living Cells. Cell Chem. Biol. 2017, 24, 404-414. [CrossRef] [PubMed]

63. Mick, D.U.; Rodrigues, R.B.; Leib, R.D.; Adams, C.M.; Chien, A.S.; Gygi, S.P.; Nachury, M.V. Proteomics of Primary Cilia by Proximity Labeling. Dev. Cell 2015, 35, 497-512. [CrossRef] [PubMed] 
64. Ting, A.Y.; Stawski, P.S.; Draycott, A.S.; Udeshi, N.D.; Lehrman, E.K.; Wilton, D.K.; Svinkina, T.; Deerinck, T.J.; Ellisman, M.H.; Stevens, B.; et al. Proteomic Analysis of Unbounded Cellular Compartments: Synaptic Clefts. Cell 2016, 166, 1295-1307.

65. Markmiller, S.; Soltanieh, S.; Server, K.L.; Mak, R.; Jin, W.; Fang, M.Y.; Luo, E.C.; Krach, F.; Yang, D.; Sen, A.; et al. Context-Dependent and Disease-Specific Diversity in Protein Interactions within Stress Granules. Cell 2018, 172, 590-604.e13. [CrossRef]

66. Lobingier, B.T.; Hüttenhain, R.; Eichel, K.; Miller, K.B.; Ting, A.Y.; von Zastrow, M.; Krogan, N.J. An Approach to Spatiotemporally Resolve Protein Interaction Networks in Living Cells. Cell 2017, 169, 350-360.e12. [CrossRef]

67. Paek, J.; Kalocsay, M.; Staus, D.P.; Wingler, L.; Pascolutti, R.; Paulo, J.A.; Gygi, S.P.; Kruse, A.C. Multidimensional Tracking of GPCR Signaling via Peroxidase-Catalyzed Proximity Labeling. Cell 2017, 169, 338-349.e11. [CrossRef]

68. Kaewsapsak, P.; Shechner, D.M.; Mallard, W.; Rinn, J.L.; Ting, A.Y. Live-cell mapping of organelle-associated RNAs via proximity biotinylation combined with protein-RNA crosslinking. Elife 2017, 6, 1-31. [CrossRef]

69. Benhalevy, D.; Anastasakis, D.G.; Hafner, M. Proximity-CLIP provides a snapshot of protein-occupied RNA elements in subcellular compartments. Nat. Methods 2018, 15, 1074-1082. [CrossRef]

70. Fazal, F.M.; Han, S.; Parker, K.R.; Kaewsapsak, P.; Xu, J.; Boettiger, A.N.; Chang, H.Y.; Ting, A.Y. Atlas of Subcellular RNA Localization Revealed by APEX-Seq. Cell 2019, 178, 473-490.e26. [CrossRef]

71. Zhou, Y.; Wang, G.; Wang, P.; Li, Z.; Yue, T.; Wang, J.; Zou, P. Expanding APEX2 Substrates for Spatial-specific Labeling of Nucleic Acids and Proteins in Living Cells. Angew. Chemie Int. Ed. 2019.

72. Sato, S.; Tsushima, M.; Nakamura, H. Target-protein-selective inactivation and labelling using an oxidative catalyst. Org. Biomol. Chem. 2018, 16, 6168-6179. [CrossRef] [PubMed]

73. Bottecchia, C.; Rubens, M.; Gunnoo, S.B.; Hessel, V.; Madder, A.; Noël, T. Visible-Light-Mediated Selective Arylation of Cysteine in Batch and Flow. Angew. Chemie Int. Ed. 2017, 56, 12702-12707. [CrossRef] [PubMed]

74. Vara, B.A.; Li, X.; Berritt, S.; Walters, C.R.; Petersson, E.J.; Molander, G.A. Scalable thioarylation of unprotected peptides and biomolecules under Ni/photoredox catalysis. Chem. Sci. 2018, 9, 336-344. [CrossRef] [PubMed]

75. Yu, Y.; Zhang, L.K.; Buevich, A.V.; Li, G.; Tang, H.; Vachal, P.; Colletti, S.L.; Shi, Z.C. Chemoselective Peptide Modification via Photocatalytic Tryptophan $\beta$-Position Conjugation. J. Am. Chem. Soc. 2018, 140, 6797-6800. [CrossRef] [PubMed]

76. Brabec, V.; Mornstein, V. Electrochemical behaviour of proteins at graphite electrodes. II. Electrooxidation of amino acids. Biophys Chem. 1980, 12, 159-165. [CrossRef]

77. Sato, S.; Morita, K.; Nakamura, H. Regulation of target protein knockdown and labeling using ligand-directed Ru(bpy)3 photocatalyst. Bioconjug. Chem. 2015, 26, 250-256. [CrossRef]

78. Page, C.C.; Moser, C.C.; Chen, X.; Dutton, P.L. Natural engineering principles of electron tunnelling in biological oxidation-reduction. Nature 1999, 402, 47-52. [CrossRef]

79. Alvarez-Dorta, D.; Thobie, C.; Croyal, M.; Bouzelha, M.; MEVEL, M.; Deniaud, D.; Boujtita, M.; Gouin, S.G. Electrochemically promoted tyrosine-click-chemistry for protein labelling. J. Am. Chem. Soc. 2018, 140, 17120-17126. [CrossRef]

80. Song, C.; Liu, K.; Wang, Z.; Ding, B.; Wang, S.; Weng, Y.; Chiang, C.-W.; Lei, A. Electrochemical oxidation induced selective tyrosine bioconjugation for the modification of biomolecules. Chem. Sci. 2019, 7982-7987. [CrossRef]

81. Toyama, E.; Marumaya, K.; Sugai, T.; Kondo, M.; Masaoka, S.; Saitoh, T.; Oisaki, K.; Kanai, M. Electrochemical Tryptophan-Selective Bioconjugation Electrochemical Tryptophan-Selective Bioconjugation. ChemRxiv 2019. [CrossRef]

(C) 2019 by the authors. Licensee MDPI, Basel, Switzerland. This article is an open access article distributed under the terms and conditions of the Creative Commons Attribution (CC BY) license (http://creativecommons.org/licenses/by/4.0/). 